\title{
ANALISIS TEKNIS MINI LINE HAULER YANG DIUJI-COBA PADA KAPAL PANCING ULUR TUNA BERBASIS DI WILAYAH PENANGKAPAN IKAN PRIGI
}

\section{TECHNICAL ANALYSIS OF MINI LINE HAULER TESTED ON TUNA HAND LINE BOAT BASED AT PRIGI FISHING GROUND}

\author{
Ignatius Tri Hargiyatno, Agustinus Anung Widodo, \& Sandi Wibowo
}

\author{
Pusat Riset Perikanan \\ Jl. Pasir Putih 1, Ancol Timur, Jakarta Utara \\ e-mail : anungwd@yahoo.co.id
}

Diterima tanggal: 6 Februari 2020 ; diterima setelah perbaikan: 10 Desember 2020 ; Disetujui tanggal: 17 Desember 2020 DOI: http://dx.doi.org/10.15578/jkn.v15i3.8672

\begin{abstract}
ABSTRAK
Penangkapan sumberdaya ikan tuna di perairan Selatan Jawa dengan menggunakan pancing ulur perairan dalam (deep hand line/dHL) dilakukan secara manual sehingga beresiko terhadap keselamatan kerja dan kualitas hasil tangkapan. Artikel ini memaparkan hasil riset ujicoba mesin penarik tali pancing (mini line hauler) di Pelabuhan Perikanan Nusantara (PPN) Prigi. Analisis teknis dilakukan untuk mendapatkan mini line haler yang cocok digunakan pada dHL dengan target tuna berbobot $100 \mathrm{~kg}$. Hasil analisis menunjukkan bahwa secara teknis mini line hauler yang cocok untuk perikanan dHL tuna yang berbasis di PPN Prigi adalah yang menggunakan sistem hidraulik dengan motor dan pompa hidraulik berkapasitas 1,62 HP dan 2,15 HP serta membutuhkan catu daya dari motor bakar atau motor listrik berkekuatan 4,23 HP.
\end{abstract}

Kata kunci : Analisis teknis, mini line hauler, pancing ulur tuna, wilayah penangkapan ikan prigi.

\begin{abstract}
Catching tuna resources using handline fishing gear in southern Java is done manually so that it risks the safety and quality of the tuna fish caught. This paper aims to conduct trials of mini line haulers on tuna handline fisheries (deep hand line/dHL) in the Prigi Nusantara Fishery Port (PPN). Technical analysis was carried out to obtain a suitable device for dHL with a target tuna weighing $100 \mathrm{~kg}$. The results of the analysis show that technically the mini line hauler suitable for the dHL tuna fishery based at the Prigi uses a hydraulic system with a motor and hydraulic pump with a capacity of $1.62 \mathrm{HP}$ and $2.15 \mathrm{HP}$ and requires a power supply from the electric motor with a power of $4.23 \mathrm{HP}$. This result can be used in developing fishing technology, especially handline tuna..
\end{abstract}

Key word : Technical analysis, mini line hauler, tuna hand line, Prigi fishing ground. 


\section{PENDAHULUAN}

Pancing ulur tuna dengan target tangkapan tuna khususnya madidihang (Thunnus albacares) dan tuna mata besar (T. obesus) ukuran $>5 \mathrm{~kg}$ disebut sebagai pancing ulur perairan dalam atau deep hand line (dHL). dHL di peraian Selatan Jawa umumnya dioperasikan menggunakan alat bantu penangkapan berupa rumpon atau fish aggregating devices (FADs) (Nurdin et al., 2012; Hargiyatno et al., 2013). Salah satu basis armada dHL adalah PPN Prigi dengan daerah penangkapan ikan di perairan Samudera Hindia (Nurdin et al., 2012). Tali pancing dHL biasanya ditarik secara manual oleh nelayan saat dHL mendapat tangkapan tuna.

Penarikan tali dHL secara manual berpotensi menimbulkan isu keselamatan dan kesehatan kerja pada nelayan dHL serta isu menurunnya mutu tuna hasil tangkapan. Isu keselamatan kerja nelayan yang sering terjadi adalah luka kulit tangan/tubuh nelayan akibat tergesek tali pancing dHL (Sekretaris Negara Republik Indonesia, 1970 tentang UU Tenaga Kerja). Nelayan juga berpotensi mengalami patah tulang dan jatuh ke laut saat menarik tali pancing dHL yang berbeban berat saat mendapat tangkapan tuna. Akibat beban kerja lebih nelayan dHL juga berpotensi menderita sakit pinggang (low back pain) dan hernia. Seperti dikatahui bahwa kekuatan optimum orang dewasa menarik beban adalah $16 \mathrm{~kg}$ (Lee et al, 2014), sementara itu dHL rata-rata menangkap madidihang berukuran $40 \mathrm{~kg}$ dengan kekuatan tarik $\pm 36.4 \mathrm{~kg}$ sehingga mengakibatkan beban kerja yang berlebih pada nelayan.. Hal ini juga menimbulkan rendahnya kecepatan tarik tali dHL saat mendapat tangkapan tuna. WWF (2011) menyampaikan bahwa pada umumnya nelayan dHL membutuhkan waktu hingga 2 jam untuk menarik tali dHL mulai dari saat tuna memakan pancing hingga ditarik mencapai dek kapal sehingga dapat menurunkan mutu ikan tuna yang tertangkap.

Terkait keselamatan dan kesehatan kerja nelayan, FAO (1995) dalam Code of Conduct for Responsible Fisheries-CCRF-Article 8.4.1 (FAO, 1995) menyampaikan bahwa negara dalam hal ini Kementerian Kelautan dan Perikanan harus dapat memastikan bahwa kegiatan operasi penangkapan ikan yang dilaksanakan telah mempertimbangkan aspek keselamatan dan kesehatan nelayan. Pada kasus dHL penggunaan pesawat bantu penarik tali dHL berupa mesin penarik tali pancing berukuran kecil (mini line hauler) diharapkan dapat mengeliminir isu-isu kesehatan dan keselamatan nelayan serta isu turunnya mutu tuna hasil tangkapannya.
Mini line hauler adalah pesawat bantu penarik tali pancing dHL yang dimodifikasi dari teknologi line hauler rawai tuna. Penggunaan line hauler pada perikanan rawai tuna atau tuna long line pertama kali tahun 1929 oleh Izui Co Ltd. di Jepang (Beverly, 2003). Bjordal \& Løkkeborg (1996) menyampaikan bahwa mekanisasi rawai tuna telah dilakukan nelayan di beberapa negara khususnya Kanada, Jerman, Islandia, Irlandia, Norwegia, Swedia, Inggris dan Amerika sejak awal 1960an. Pada umumnya line hauler rawai tuna berukuran besar dengan berat per $>200 \mathrm{~kg} / \mathrm{unit}$ dengan spesifikasi teknis sesuai dengan kebutuhan sebagai pesawat bantu penarik tali rawai tuna. Bahkan line hauler rawai tuna versi H3200 (Mustad Co Ltd, 2014) mempunyai berat hingga $1099 \mathrm{~kg} / \mathrm{unit}$. Mini line hauler dirancang berukuran lebih kecil yaitu $<100 \mathrm{~kg} /$ unit dengan konstruksi relatif sederhana sesuai kebutuhan operasional dHL. Walaupun relatif lebih sederhana, secara fungsional mini line hauler pada dHL adalah sama dengan line hauler pada rawai tuna. Sistem hidraulik dipilih sebagai transmisi tenaga penggerak mini line hauler, hal ini dikarenakan sistem hidraulik bersifat handal, efisien, dan relatif murah (Fisher, 1971; Aryoseto, 2010). Di dalam memodifikasi line hauler untuk rawai tuna menjadi mini line hauler untuk dHL memerlukan analisis teknis terkait berbagai pembatas seperti halnya (1) kekuatan yang ditimbulkan tuna saat tertangkap dHL, (2) kekuatan putus tali dHL, (3) ketersedian konponen utama sistem hidraulik khususnya motor hidraulik, pompa hidraulik dan penggerak pompa hidraulik di pasaran. Tulisan ini menyampaikan hasil analisis teknis aspek-aspek yang merupakan pembatas yang harus dipenuhi sehingga diperoleh rancang bangun dan konstruksi mini line hauler yang cocok untuk digunakan pada dHL. Tulisan ini membahas analisis teknis mini line hauler untuk armada dHL yang berbasis di Pelabuhan Perikanan Nusantara (PPN) Prigi-Jawa Timur.

\section{BAHAN DAN METODE}

Aspek-aspek teknis yang dianalisis dalam membangun/ membuat mini line hauler pada dHL di kelompokkan menjadi 3 yaitu:

- tenaga yang ditimbulkan ikan tuna saat tertangkap dHL,

- $\quad$ kekuatan putus (breaking load) tali pancing dHL yang biasa digunakan nelayan,

- kekuatan komponen sistem hidraulik, khususnya motor dan pompa hidraulik mini line hauler.

Tenaga yang ditimbulkan ikan tuna khususnya madidihang dianalisis berdasarkan ukuran bobot 
maksimum madidihang (Thunnus albacares ) yang biasa tertangkap nelayan dHL berbasis di Pelabuhan Perikanan Nusantara (PPN) Prigi. Data dan informasi ukuran bobot tuna khususnya madidihang (Thunnus albacares) yang tertangkap dHL adalah berasal dari hasil kegiatan enumerator bulan Januari-Maret 2015. Estimasi kekuatan atau tenaga yang ditimbulkan oleh tuna khususnya madidihang (Thunnus albacares) saat terkena pancing dHL dianalisis berdasarkan hasil penelitian Junchi et al. (2015) dan Haiyang et al. (2016) seperti disajikan pada formula 1 dan 2.

$\mathrm{F}_{\mathrm{i}}=0,30 \mathrm{~W}(\mathrm{~N})$

$\mathrm{F}_{\mathrm{d}}=0,91 \mathrm{~W}(\mathrm{~N})$

Dimana $\mathrm{Fj}$ adalah static force saat madidihang dalam keadaan tidak berenang atau diam. Adapun Fd adalah dynamic force yaitu tenaga madidihang yang timbul dengan kecepatan renang maksimum yaitu $20 \mathrm{~m} /$ detik (Junchi et al., 2015; Walters \& Fierstine, 1964). Fd yang ditimbukan tuna madidihang merepresentasikan tenaga yang dibutuhkan untuk menarik tali dHL saat tuna madidihang memakan pancing dHL dengan kecepatan renang $20 \mathrm{~m} /$ detik. W adalah berat tuna madidihang di udara dalam $\mathrm{kg}$.

Tali pancing yang biasa digunakan pada dHL mempunyai diameter (Ø) tertentu. Estimasi kekuatan putus tali pancing dHL dianalisis berdasarkan grafik (Gambar 1) yang dikemukakan Prado (1990), yaitu saat tali senar nilon (monofilament) dalam keadaan basah.

Estimasi kekuatan motor hidraulik $\left(\mathrm{P}_{\mathrm{i}}\right)$ dihitung berdasarkan beban yang ditimbulkan oleh tenaga (kekuatan) ikan madidihang dalam kondisi dinamis $\left(\mathrm{F}_{\mathrm{d}}\right)$ dengan kecepatan renang maksimum yaitu $20 \mathrm{~m} /$ detik dan kecepatan tarik tali pancing dHL optimal yaitu $60 \mathrm{~m} / \mathrm{menit}$ (Coon, et al., 2012) dengan formula 3:

$$
P_{i}=\frac{F_{d} \times V}{5252 \times 2 \Pi}
$$

dimana,

$\mathrm{Pi}=$ kekuatan tarik ikan tuna yang akan ditanggung motor hidraulik dalam $\mathrm{kW}$ atau $\mathrm{HP},(1 \mathrm{~kW}=1,34 \mathrm{HP})$ dan $(1 \mathrm{kgf} \cdot \mathrm{m}=0,0000037 \mathrm{HP}) . \mathrm{Fd}=$ kekuatan tarik ikan tuna pada kecepatan renang $20 \mathrm{~m} /$ det dalam N. V $=$ kecepatan tali mini line hauler saat ditarik yaitu 60 $\mathrm{m} / \mathrm{menit}$.

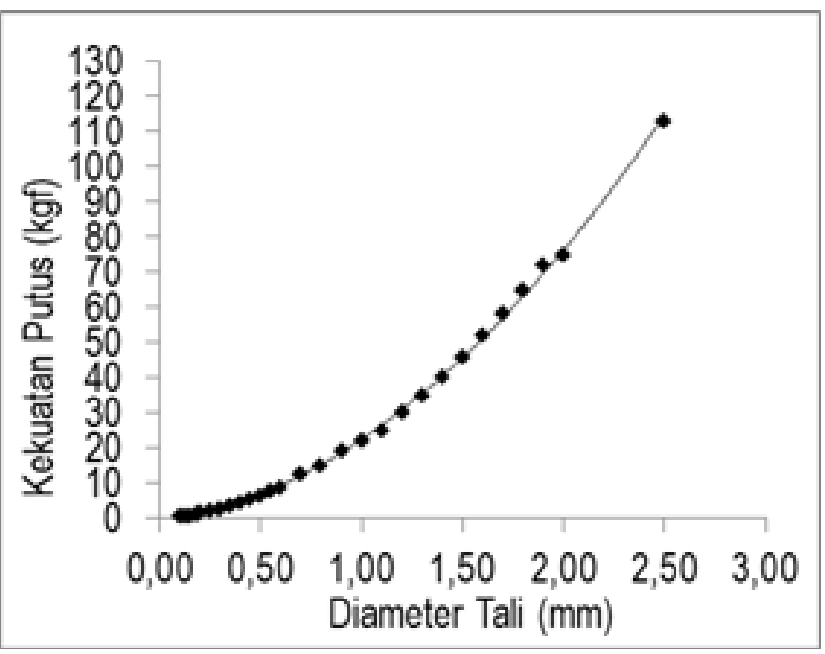

Gambar 1. Grafik kekuatan putus tali mono filament. (dimodifikasi dari Prado, 1990).

Figure 1. Graphic of breaking load of monofilament yarn. (modified from Prado, 1990).

Estimasi kekuatan pompa hidraulik dianalisis dengan formula 4 :

$$
P_{p}=P_{m} \times 0,83^{-1}
$$

dimana,

$\mathrm{P}_{\mathrm{p}}=$ kebutuhan tenaga pemutar pompa hindraulik, $\mathrm{Pm}$ $={ }_{\mathrm{p}}^{\mathrm{p}}$ ebutuhan tenaga motor hidraulik yaitu setara dengan kekuatan tarik ikan (Pi) dan 0,83 adalah faktor efisiensi (EF) sistem hidraulik (Fisher, 1971). Perhitungan EF biasanya mempertimbangkan nilai-nilai friksi yang ditimbulkan oleh aliran fluida hidraulik pada pipa-pipa dan katup-katup sistem hidraulik serta gesekan antar komponen unit mini line hauler yang bergerak. Nilai Pp yang telah diperoleh digunakan untuk mengestimasi besarnya daya catu yaitu $\mathrm{kW}$ atau HP motor listrik atau motor bakar yang harus disediakan. Pada mini line hauler nilai Pp setara Pm.

\section{HASIL DAN PEMBAHASAN}

\section{Ukuran Ikan Tuna}

Hasil tangkapan pancing dHL di sekitar rumpon yang didaratkan di PPN Prigi bulan Januari-Maret 2015 lebih dari $90 \%$ adalah jenis madidihang (Thunnus albacares), sehingga perhitungan estimasi kekuatan ikan didasarkan kekuatan ikan tuna madidihang (Thunnus albacares). Ukuran (bobot) ikan madidihang yang tertangkap dHL berkisar 1,5-93 kg per ekor. 


\section{Ukuran Tali dHL}

Hasil penelitian di Prigi menunjukkan bahwa tali pancing dHL yang digunakan nelayan yang berbasis di PPN Prigi umumnya berbahan nylon monofilament berdiameter (Ø) 2,5 mm. Pengoperasian dHL adalah disekitar rumpon. Hasil wawancara dengan nelayan menunjukkan bahwa pemilihan tali pancing $\mathrm{dHL}$ ber- $\varnothing$ 2,5 mm adalah cukup untuk menarik ikan sebarat 90$100 \mathrm{~kg}$.

\section{Kekuatan motor dan pompa hidraulik}

Penggunaan motor dan pompa hidraulik pada sistem hidraulik mini line hauler yang dibangun sangat tergantung pada ketersediaannya di pasaran. Pada saat ini kapasitas terkecil motor dan pompa hidraulik yang tersedia di pasaran Indonesia masing-masing 16,5 HP dan 20,5 HP. Jenis motor dan pompa hidraulik adalah tipe gear, dengan fluida hidraulik bervikositas (SAE) 10W. Motor hidraulik yang digunakan pada sistem hidraulik mini line hauler in adalah tipe roda gigi (gear type) MTR-01 Zhenjiang Motor BMRS-80-H2 dengan spesifikasi sebagaimana disajikan dalam Tabel 1 . Pompa hidrolik yang digunakan pada mini line hauler adalah tipe roda gigi eksternal Pmp-01Liuzhou Gear Pump KP-75 A dengan spesifikasi seperti disajikan dalam Tabel 2.

\section{Catu daya penggerak pompa hidraulik}

Catu daya yang digunakan untuk menggerakkan pompa hidraulik ada dua macam yaitu menggunakan motor bakar dan motor listrik. Pada uji coba ini, catu daya penggerak pompa hidraulik diambil dari motor bakar yaitu mesin induk atau main engine (M/E) kapal dHL atau motor bakar jenis diesel. Ukuran kapal dHL yang berbasis di PPN Prigi umunya berukuran 10-18 GT dengan kekuatan M/E antara 40-60 HP dan kecepatan layar (service speed) umumnya 8 knot. Pompa hidraulik dihubungkan dengan $\mathrm{M} / \mathrm{E}$ dengan belt pulley.

Tabel 1. Spesifikasi*) motor hidraulik yang digunakan mini line hauler

Table 1. Specification*) of hydralic motor used in the mini line hauler

\begin{tabular}{lll}
\hline Type (tipe) & $:$ & MTR-01 \\
Brand (merek dagang) & $:$ & Zhenjiang Motor BMRS-80-H2 \\
Displacement (volume perpindahan fluida) & $:$ & $80,6 \mathrm{~cm} 3 / \mathrm{rev}$. \\
Max. RPM (kecepatan putar maksimum.) & $:$ & $750 \mathrm{rpm}$. \\
Max. torque rated (torsi maksimum.) & $:$ & $160 \mathrm{~N} * \mathrm{~m}$. \\
Max. output rated (Luaran maksimum) & $:$ & $12,3 \mathrm{~kW}(16,5 \mathrm{HP})$. \\
Max. pressure rated (Tekanan maksimum) & $:$ & $14 \mathrm{Mpa}$. \\
Min. pressure rated at start (tekanan awal) & $:$ & $10 \mathrm{Mpa}$ \\
Max. Flow of fluid (aliran fluida maksimum.) & $:$ & $601 / \mathrm{m}$. \\
Min. flow at start (aliran fluida awal putaran) & $:$ & $201 / \mathrm{m}$. \\
Weight (Berat) & $:$ & $6,9 \mathrm{~kg}$.
\end{tabular}

*) Spesifikasi motor hidraulik dipilih berdasarkan ketersediaannya di pasar.

*)__ The specification of hydraulic motor was choosen base on availabity in market.

Tabel 2. Spesifikasi pompa hidrolik yang digunakan pada mini line hauler yang diujicoba tahun 2015

Table 2. Specification*) of hydralic pump used in the mini line hauler

\begin{tabular}{lll}
\hline Type & $:$ & PMP-01 Hydraulic Pump \\
Brand & $:$ & Liuzhou Gear Pump KP-75 A \\
Displacement & $:$ & $72 \mathrm{ml} / \mathrm{rev}$. \\
Rated RPM & $:$ & $800 \mathrm{rpm}$. \\
Minimum RPM & $:$ & $350 \mathrm{rpm}$. \\
Maximum RPM. & $:$ & $1800 \mathrm{rpm}$. \\
Minimum output & $:$ & $3,51 \mathrm{HP}$ \\
Maximum output & $:$ & $20,56 \mathrm{HP}$ \\
Highest Pressure & $:$ & $210 \mathrm{kgf} / \mathrm{cm} 2$. \\
Control Stem Wire F. & $:$ & $14 \mathrm{gk}$ \\
Weight & $:$ & $21 \mathrm{~kg}$. \\
\hline
\end{tabular}

*)___ Spesifikasi pompa hidraulik dipilih berdasarkan ketersediaannya di pasar.

*) The specification of hydraulic pump was choosen base on availabity in market. 
Disain, konstruksi dan pemasangan mini line hauler pada kapal dHL.

Disain dan konstruksi mini line hauler yang dibangun disajikan pada Gambar 2. Komponen penggulung tali terdiri dari line spool plate terbuat dari bahan kuningan (bronze) Ø 225mm, cakram penekan (pressure idler plate) dari bahan kuningan $\varnothing 110 \mathrm{~mm}$ dan cakram penarik tali (line pulling sheave plate) dua buah berbahan kuningan berlapis karet $\varnothing 70 \mathrm{~mm}$ dan $100 \mathrm{~mm}$ Cakram penggulung (line spool plate) digerakan oleh motor hidraulik dimana poros keduanya dihubungkan secara horizontal. Kerengganggan line spool plate dan line pulling sheave plate dapat diatur sehingga bisa digunakan untuk menarik dan menggulung tali $\varnothing 1$ $10 \mathrm{~mm}$. Tiang penopang (support pole/stanchion) mini line hauler terbuat dari pipa baja $\varnothing 70 \mathrm{~mm}$ dan total tinggi $850 \mathrm{~mm}$. Bobot total unit mini line hauler adalah $80 \mathrm{~kg}$. Motor hidraulik digerakkan fluida hidraulik yang didorong oleh pompa hidraulik dan pompa hidraulik digerakkan dengan mesin induk kapal (main engine) dengan belt pulley.

Mini line hauler diuji coba pada kapal dHL bernama KM. Berdikari 02, yaitu salah satu kapal dHL milik nelayan yang bebasis di PPN Prigi. Spesifikasi KM. Berdikari 02 adalah sebagai berikut : panjang kesluruhan (Loa) $18,00 \mathrm{~m}$, lebar $\left(\mathrm{B}_{\max }\right) 3,40 \mathrm{~m}$ dan dalam $\left(\mathrm{d}_{\max }\right) 1,65 \mathrm{~m}$ atau berbobot $15 \mathrm{GT}$. Tenaga penggerak (M/E) 2 × 30 $\mathrm{HP}$ serta mesin generator $(\mathrm{G} / \mathrm{E})$ berkapasitas $5 \mathrm{HP}$ atau sekitar 3,8 kVA. Kecepatan normal (service speed) 8 knot dan kecepatan saat menarik tali pancing $\mathrm{dHL}$ adalah 1 knot. Pompa hidraulik unit mini line hauler mendapat tenaga pemutar dari mesin induk kapal yang dihubungkan (coupled) dengan pulley belt. Gambar 3 adalah tampak atas (top view) dan Gambar 4 adalah tampak samping (side view) skema pemasangan unit mini line hauler dan sistem hidraulikya di KM. Berdikari 02

\section{Kekuatan tarik ikan}

Hasil pengamatan di PPN Prigi menunjukkan bahwa \pm 90\% tuna yang tertangkap dHL adalah tuna madidihang (Thunnus albacares). Bobot tuna madidihang yang tertangkap dHL nelayan yang berbasis di PPN Prigi bervariasi antara 1,5 - $93 \mathrm{~kg}$ per ekor. Selanjutnya diasumsikan bahwa ikan tuna madidihang terbesar yang akan tertangkap dHL adalah berbobot $100 \mathrm{~kg}$. Kecepatan renang ikan tuna madidihang maksimum 20

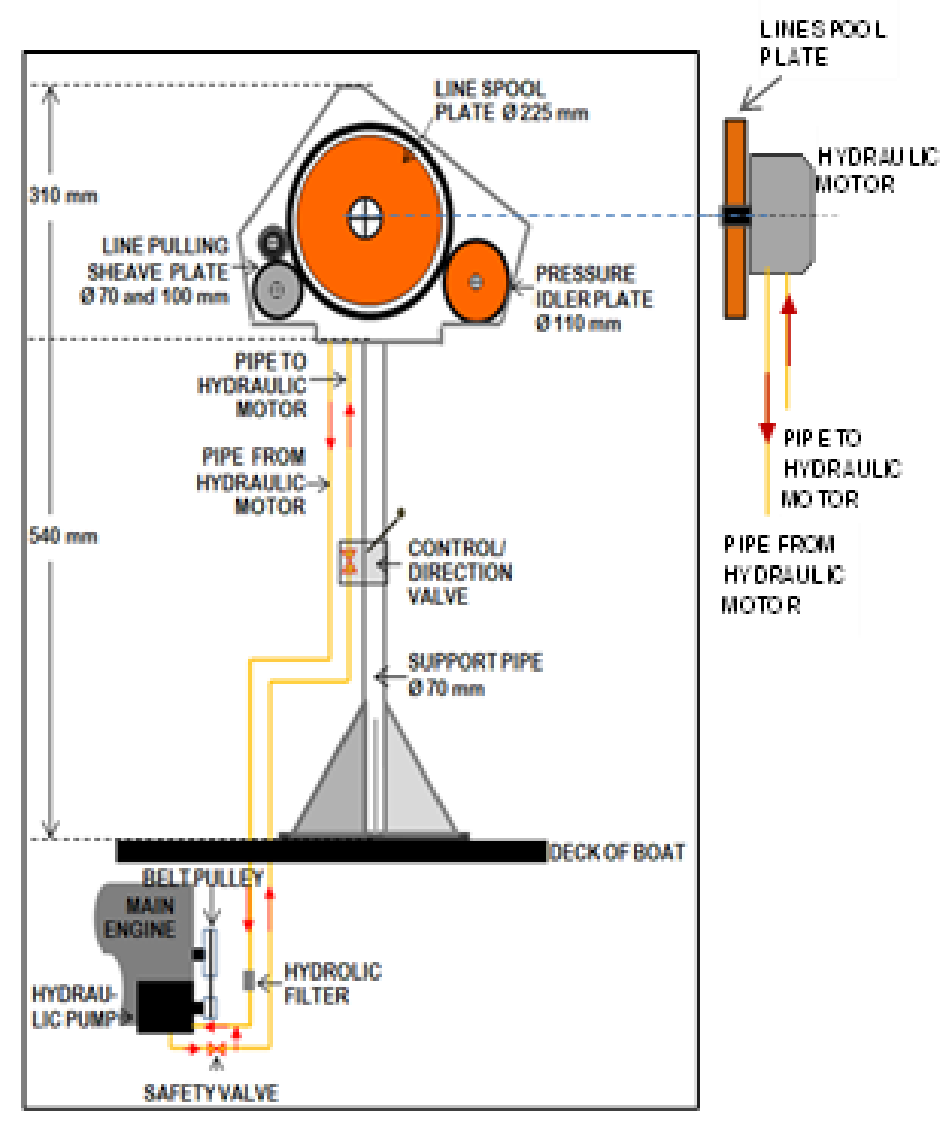

Gambar 2. Disain dan konstruksi unit mini line hauler dengan sistem hidrauliknya.

Figure 2. Design and construction of the mini line hauler and its hydraulic system.

Analisis Teknis Mini line hauler Yang Diuji-Coba pada Kapal Pancing Ulur Tuna Berbasis di Wilayah Penangkapan Ikan Prigi - Ignatius Tri Hargiyatno, Agustinus Anung Widodo, \& Sandi Wibowo 


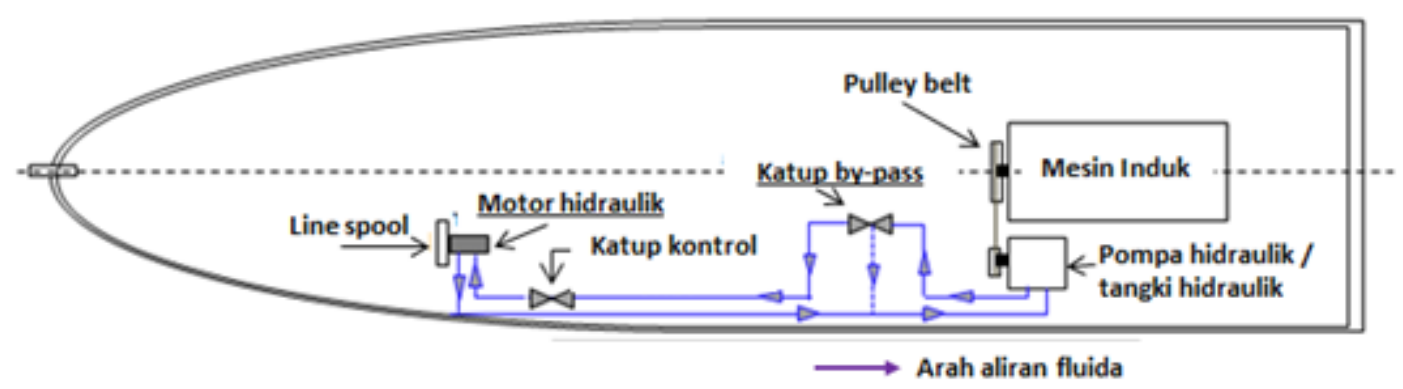

Gambar 3. Tampak atas skema pemasangan unit mini line hauler di KM. Berdikari 02.

Figure 3. Top view of schematic diagram of KM. Berikari 02 's mini line hauler hydraulic system.

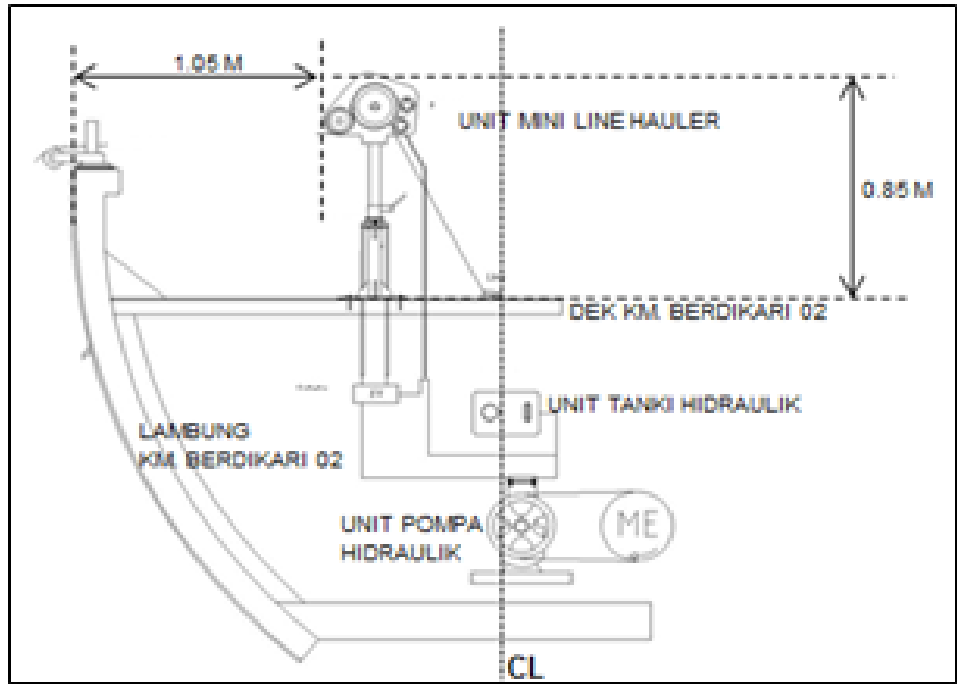

Gambar 4. Tampak samping skema pemasangan mini line hauler di KM. Berdikari 02.

Figure 4. Side view of schematic diagram mini line hauler hydraulic system in KM. Berdikari 02.

m/detik (Walters \& Fierstine, 1964). Sesuai formula (2) seperti yang disampaikan Junchi et al. (2015) dan Haiyang et al. (2016) maka estimasi kekuatan tarik ikan atau $\mathrm{Fd}$ madidihang berbotot $100 \mathrm{~kg}$ tersebut mencapai $892 \mathrm{~N}$ atau $\pm 92 \mathrm{kgf}$.

\section{Kekuatan tali pancing dHL}

Pada umumnya diameter tali utama dHL yang digunakan nelayan yang berbasis di PPN Prigi adalah $2,5 \mathrm{~mm}$, maka estimasi kekuatan putus (breaking load) pada kondisi basah adalah $\pm 113 \mathrm{kgf}$ (Prado, 1990). Jika mengacu pada formula yang dikemukakan Junchi et al. (2015) dan Haiyang et al. (2016), maka tali pancing dengan breaking load $113 \mathrm{kgf}$ akan mampu digunakan untuk menarik ikan madidihang berbobot $\pm 124 \mathrm{~kg}$. Estimasi bobot sumberdaya ikan tuna yang tertangkap longline berada pada ukuran < $100 \mathrm{~kg}$, sedangkan handline berada kurang dari 90 kg (Hartaty \& Sulistyaningsih, 2014; Agustina et al., 2019). Sehingga kekuatan tali pancing ini masih mampu digunakan untuk menangkap sumberdaya ikan tuna madidihang yang terangkap longline maupun hand line.

\section{Kapasitas motor dan pompa hidraulik}

Mengacu pada Formula 3, jika kecepatan tarik tali pancing adalah 60 meter/menit (Coon, et al. , 2012) maka motor hidraulik akan mendapat beban 1,62 horse power (HP). Dengan mempertimbangkan kepentingan keselamatan peralatan maka biasanya kapasitasnya ditambah $10 \%$ dari kapasitas maksimum beban yang dibutuhkan, sehingga kapasitas motor mini line hauler menjadi 1,78 HP. Kapasitas pompa hidraulik yang dihitung berdasarkan Formula 4, yaitu dengan faktor efisiensi (EF) yaitu $83 \%$, sehingga kapasitas pompa hidraulik yang dibutuhkan pada mini line hauler adalah 2,15 HP.

Melihat kapasitas yang dimiliki motor hidraulik dan pompa hidraulik yang tersedia (Tabel 1 dan Tabel 2) maka kapasitas tersebut masih terlalu tinggi dibanding kapasitas motor dan pompa hidraulik untuk keperluan mini line hauler dHL yang berbasis di PPN. Prigi. Namun saat ini di pasaran di Indonesia belum tersedia 
Tabel 3. Resume analisis teknis line hauler dHL yang diujicoba di PPN Prigi tahun 2015 Table 3. Resume of technical annalysis $d H L$ which is tested in Prigi year of 2015

Bobot ikan madidihang

Tenaga ikan yang dikeluarkan (Fd) dengan kecepatan renang 20 m/detik. Kapsitas motor hidraulik untuk menarik beban ikan madidihang sebesar $92 \mathrm{kgf}$ dengan kecepatan tarik pancing dHL 60m/menit.

Kapsitas motor hidraulik dengan toleransi keamanan 10\%

Kapasitas pompa hidraulik dengan nilai EF sistem hidraulik 0,83.

Kapasitas tenaga motor bakar untuk menggerakan pompa hidraulik dengan EF 0,83.
$100 \mathrm{~kg}$

$92 \mathrm{~kg}$-force.

$1,62 \mathrm{HP}$

$1,78 \mathrm{HP}$

$2,15 \mathrm{HP}$

4,23 HP motor dan pompa dengan kapasitas sesuai kebutuhan sistem hidraulik mini line hauler.

\section{Kebutuhan catu daya penggerak pompa hidraulik} Jika pompa pompa hidraulik tipe PMP-01-Gear Pump KP-75A dengan minimum output 3,51 HP (Tabel 2), maka untuk memutar motor hidraulik berbeban 2,15 HP adalah cukup memadai. Mengacu pada EF umumnya pada sistem hidraulik yaitu 0,83 , maka agar output pompa hidraulik 3,51 HP pada putara $350 \mathrm{rpm}$ diperlukan input dari motor bakar atau motor listrik sebesar 4,23 HP (Tabel 3).

Motor bakar penyedia catu daya penggerak pompa hidraulik unit mini line hauler pada ujicoba di KM. Berdikari 02 adalah berasal dari mesin induk kapal. Seperti telah disebutkan bahwa dengan kekuatan mesin induk kapal sebesar $60 \mathrm{HP}$, maka kecepatan (service speed) kapal adalah 8 knot. Pada saat menarik pancing dHL secara manual (tanpa mini line hauler) kecepatan KM. Berdikari 02 adalah 1 knot atau hanya membutuhkan tenaga sekitar 7,5-8,0 HP atau sekitar $13 \%$ dari total kekuatan mesin induk yaitu 60 HP. Pemasangan unit mini line hauler yang tenaganya diambil dari mesin induk menambah beban mesin induk sebasar 4,23 HP atau $\pm 7,05 \%$ dari $60 \mathrm{HP}$ tidak mengganggu performansi (kecepatan saat menarik tali pancing dan oleh gerak) KM. Berdikari 02.

\section{KESIMPULAN DAN SARAN}

Dari uraian tersedut di atas maka dapat disimpulkan bahwa :

1. Mini line hauler $\mathrm{dHL}$ tuna yang berbasis di Pelabuhan Perikanan Nusantara (PPN) Prigi didesain untuk menangkap tuna hingga ukuran hingga $100 \mathrm{~kg}$.

2. Mini line hauler $\mathrm{dHL}$ tuna tersebut digerakkan dengan sistim hidraulik, kapasitas motor dan pompa hidraulik masing-masing 1,62 HP dan 2,15 HP. Kebutuhan catu daya dari motor bakar adalah

\section{4,23 HP.}

3. Saat ini motor dan pompa yang tersedia dipasaran berkapasitas terkecil masing-masing 16,5 HP dan 20,5 HP sehingga secara teknis tidak efisien jika digunakan untuk keperluan sistem hidraulik mini line hauler dHL. Pengembangan ke arah produk masal disarankan untuk dapat menggunakan motor dan pompa hidraulik berkapasitas sesuai kebutuhan dengan menjajaki pasar tempat lain yaitu luar Indonesia.

\section{UCAPAN TERIMA KASIH}

Penulis mengucapkan terima kasih kepada, Bapak Kusno kepala bengkel pembuatan pesawat bantu penangkapan ikan di PPS Nizam Zachman-Jakarta yang telah banyak memberikan saran dalam pembuatan mini line hauler, SMK Negeri I Watuliomo Prigi yang telah mengikut sertakan 2 siswanya sebagai teknisi lapangan dalam ujicoba mini line hauler.

\section{DAFTAR PUSTAKA}

Agustina, M., Setyadji, B., \& Tampubolon, P.A.R.P (2019) Perikanan Tuna Sirip Kuning (Thunnus albacares Bonnaterre, 1788) pada Armada Tonda di Samudera Hindia Selatan Jawa. BAWAL. 11 (3): 161-173

Aryoseto, J. (2010). Pembuatan Alat Peraga Sistem Hidolik. Proyek akhir pada program Diploma III Teknik Mesin Produksi Fakultas Teknik Universitas Sebelas Maret Surakarta (tidak diterbitkan). 74 hal.

Beverly, S., Chapman, L., \& Sokimi, W. (2003). Horizontal long-line fishing methods and techniques: a manual for fishermen. Secretariat of the Pacific Community (SPC). New Caledonia. ISBN 982-203-937-9. p.130. 
Bjordal, Å. \& Løkkeborg, S. (1996). Long lining. Oxford [England] : Fishing News Books. Osney Mead. ISBN : 0852382006 9780852382004:156p

FAO (1995) . Code of cunduct for responsible fisheries ISBN 92-5-103834-5. Rome, FAO. 1995. 41 p.

Haiyang, L., Liming, S., Junting, Y., \& Junchi, M.A. (2016). The mechanical properties of ring hook and circle hook, Journal of Fisheries of China , 40(6), 965-975. 1000-0615(2016)06-0965-11, DOI: $10.11964 /$ jfc.20150709997, .

Hargiyatno, I. T., Anggawangsa, R. F., \& Wudianto (2013). Perikanan Pancing ulur di Pelabuhan Ratu. Jurnal Penelitian Perikanan Indonesia, 19 (3), 121-130.

Hartaty, H., \& Sulistyaningsih R. K. (2014) Pendugaan Parameter Populasi dan Tingkat Pemanfaatan Ikan Madidihang (Thunnus albacares) yang Didaratkan di Benoa, Bali. J. Lit. Perikan. Ind, 20(2), 87-103

Junchi, M. A., Junting, Y., \& Liming, S. (2015). Mechanical properties of tuna long-line hook based on finite element analysis method). Journal of Fisheries of China, 39(11), 1742-1751. 1000-0615 (2015) 11-1742-10, DOI:10.11964/ jfc.201410009500,

Lee, J., Nussbaum, M. A., \& Kyung, G. (2014). Effect of work experience on work methods during dynamic pushing and pullung. Elsevier : International Journal of Ergonomics, 44(2014), 647-653.

Mustad Co Ltd. (2014). Super Hauler TM New Version H3200. http://issuu/mustad-autline/docs/2014 01 autline_deapsea_system $/ 8$.

Nurdin, E., Taurusman, A. A., \& Yusfiandayani, R. (2012). Optimasi jumlah rumpon, unit armada dan musim penangkapan perikanan tuna di Perairan Prigi, Jawa Timur. Jurnal Penelitian Perikanan Indonesia, 18(1), 53-60

Prado, J. (1990). Fisherman's Workbook. Fishery Industries Division, Food And Agriculture Organization (FAO) of The United Nations by Fishing News Books Oxford. ISBN 0-85238163-8. 161p.
Undang-Undang No 1 tahun 1970. Tentang keselamatan kerja. Diundangkan di Jakarta pada tanggal 12 Januari 1970. 11 Bab-18 Pasal. p.18.

Walters, V., \& Fierstine, H. L. (1964). Measurements of Swimming Speeds of Yellowfin Tuna and Wahoo Nature, 202(4928), 208-209.

WWF. (2011). Perikanan Tuna. Panduan Penangkapan dan Penanganan. Seri Panduan Perikanan Skala Kecil. Versi 1 Oktober 2011. 26p.

Sekretaris Negara Republik Indonesia. (1970). 